\title{
Abbreviations for Texts by James Joyce
}

\author{
CP Collected Poems \\ CW The Critical Writings of James Joyce \\ D Dubliners \\ E Exiles
}

FW Finnegans Wake, cited by page and line number

Letters Letters of James Joyce

$P \quad$ A Portrait of the Artist as a Young Man

A Portrait of the Artist as a Young Man: Text, Criticism, and Notes

SH Stephen Hero

SL Selected Letters of James Joyce

$U \quad$ Ulysses, I96I Random House edition cited by page number; I 984 and 1986 Hans Walter Gabler editions cited by episode and line number 
